\title{
Polityka gospodarcza i społeczna Sojuszu Lewicy Demokratycznej (2001-2005) a program ideowy lewicy
}

\section{Wstęp}

Ewolucja programowa Sojuszu Lewicy Demokratycznej stanowi jedno z najbardziej intrygujących zjawisk politycznych charakteryzujących IV kadencję sejmu, stając się dzięki temu przedmiotem badań politologów i historyków ${ }^{1}$. Na jej wyjątkowość składa się szereg czynników, m.in. spektakularna wygrana w wyborach parlamentarnych w 2001 r. Sojuszu Lewicy Demokratycznej, jego początkowo wysokie poparcie i szybki spadek popularności, a także dyskusyjne, dalekie od lewicowości działania ówczesnego rządu.

Problem badawczy zawiera się w pytaniu o przyczyny ewolucji programowej SLD w latach 2001-2005. W toku prowadzonych analiz została postawiona główna hipoteza, iż na odejście partii Leszka Millera od lewicowych zasad miały wpływ szeroko pojęte czynniki egzogeniczne oraz endogeniczne, w tym problemy dotyczące polityki gospodarczej i społecznej. Niemniej omawiane zmiany wiązały się z działaniami rządu, które w głównej mierze opierały się na bieżącym zarządzaniu, tj. doraźnych poszukiwaniach rozwiązań uzależnionych od zastanej lub zaistniałej sytuacji społecznoekonomicznej w kraju.

Praca powstała przede wszystkim na podstawie materiałów źródłowych, wśród których najważniejsze to: Raport otwarcia. Stan polskich spraw u progu działania rządu SLD - UP i PSL sporządzony przez Kancelarię Prezesa Rady Ministrów w 2001 r., Program wyborczy koalicji SLD-UP 2001 oraz Expose Prezesa Rady Ministrów Leszka Millera z 2001 roku udostępnione przez Kancelarię Prezesa Rady Ministrów. Na uwagę zasługuje także kilka opracowań takich jak: Historia polityczna Polski 1989-2005

\footnotetext{
${ }^{1}$ Ł. Tomczak, Lewicowe partie polityczne w Polsce. Programy, organizacja, strategie, Szczecin 2012; A. Dudek, Historia polityczna Polski 1989-2005, Kraków 2007; Lewica w III RP. Lewica w praktyce rzq̨dzenia, red. D. Waniek, Torun 2010; D. Sieklucki, Partie lewicy i centrolewicy w polskim systemie partyjnym, Kraków 2006.
} 
Antoniego Dudka, Trzecia Rzeczpospolita (1989-2007) Włodzimierza Bonusiaka, Rzq̨dy koalicyjne III RP zredagowane przez Marka Chmaja oraz szereg artykułów prasowych opublikowanych m.in. w „Polityce” czy „Tygodniku Powszechnym”.

Metodą pozwalającą na rozpoznanie wspomnianego problemu jest analiza systemowa $^{2}$ uzupełniona analizą historyczną ${ }^{3}$. Natomiast podczas porównywania kwestii gospodarczych i społecznych wykorzystano podejście problemowe.

\section{Polityka gospodarcza}

Raport otwarcia nowego rządu powstał pod koniec 2001 r. w celu diagnozy stanu polskiej gospodarki. Autorzy dokumentu zwrócili uwagę m.in. na nienajlepszą kondycję ekonomiczną kraju oraz szereg innych problemów. Pogłębiająca się dziura budżetowa, spadek wzrostu gospodarczego, rosnące bezrobocie czy niekorzystne skutki finansowe wcześniejszych reform to tylko część zarzutów kierowanych do poprzedniego gabinetu. W exposé premier Leszek Miller podkreślił potrzebę szybkiej i skutecznej naprawy sytuacji pieniężnej Skarbu Państwa4, prezentując szereg planowanych przez swój rząd ulepszeń w gospodarce. Kilka miesięcy później, w styczniu 2002 r., koalicja SLD-UP-PSL przyjęła program gospodarczy na najbliższe lata. Jego koncepcje zakładały wsparcie rozwoju infrastruktury i budownictwa mieszkaniowego opartego na preferencyjnych kredytach, a także kontynuację procesu prywatyzacji nierentownych przedsiębiorstw państwowych, co doprowadziło ostatecznie do wzrostu gospodarczego na poziomie 5 proc. w roku 2005. W międzyczasie minister finansów zapowiedział wprowadzenie planowanego pakietu udogodnień dla przedsiębiorczości, zmiany w przepisach o stosunku pracy, w tym zmniejszenie kosztów zatrudnienia pracownika. Ministerstwo zamierzało także zająć się wnioskami o zamianę kwoty wolnej od podatku na tzw. „zerowy PIT”, dzięki któremu uzyskane pieniądze byłoby można przeznaczyć na pomoc finansową dla najmniej zarabiających. Kolejne punkty programu gospodarczego obejmowały m.in. kompleksowe uszczelnienie systemu ubezpieczeń rolniczych (KRUS). Procesowi realizacji wszystkich warunków miało natomiast towarzyszyć

\footnotetext{
2 J. Kowalik, W. Szostak, Metodologiczne problemy nauk o polityce dla studentów nauk politycznych, Kielce 2007, s. 210-211.

3 A. Chodubski, Wstęp do badań politologicznych, Gdańsk 2004, s. 119, 127-128.

4 J. Paradowska, Premiera Millera, „Polityka” 2001, nr 44, s. 15.
} 
monitorowanie oraz korekta wzrostu wydatków budżetowych pozostających na umiarkowanym poziomie 5 .

\section{Finanse państwa, przedsiębiorczość oraz infrastruktura drogowa}

Jednym z pierwszych przedsięwzięć rządu w ratowaniu finansów państwa stało się

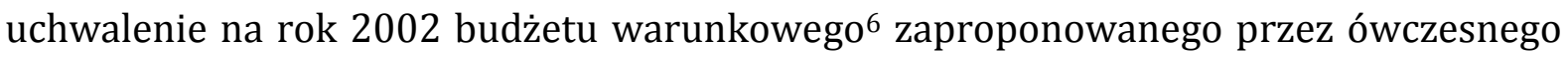
ministra finansów Marka Belkę. Zakładano duże cięcia w wydatkach, których dopuszczalny wzrost mógł wynosić wskaźnik inflacji plus jeden punkt proc. W toku prac nad poprawą finansów Belka zaproponował wdrożenie planu „łatania dziury budżetowej”. Ograniczeniu wydatków państwa przez zawieszenie podwyżek dla pracowników oświaty, zamrożenie progów podatkowych ${ }^{7}$ czy wysokości pensji w tzw. budżetówce, towarzyszyło zwiększenie uzyskiwanych dochodów. Rząd przyjął zapowiadany pakiet ustaw okołobudżetowych, które obniżyły wysokość płac urzędników i skorygowały finanse przeznaczone dla pomocy społeczneje, następnie zdecydował się na wprowadzenie podatku dochodowego od przychodów kapitałów pieniężnych (zwany „podatkiem Belki”) oraz akcyzy na energię elektryczną. W międzyczasie doszło do redukcji dopłat, jakie państwo przekazywało dwóm przedsiębiorstwom: Polskim Kolejowym Państwowym i Przedsiębiorstwu Komunikacji Samochodowej. Bilety bezpłatne zamieniono na ulgi 78 proc., a 50 proc. ulgi zostały zmniejszone do 37 proc., co miało w pewnym stopniu odciążyć państwowy budżet i pomniejszyć wydatki ${ }^{9}$. W przypadku postulatu Ministerstwa Finansów o podniesienie VAT na niektóre materiały budowlane nie doszło do realizacji. Sprzeciw zgłosiło PSL, które żądało podjęcia przez rząd działań wpływających na decyzje Rady Polityki Pieniężnej (RPP) oraz obniżenie stóp procentowych. Pomysł zakwestionował prezydent Aleksander Kwaśniewski, broniąc niezależności Narodowego Banku Polskiego i RPP. Również dwukrotna próba PSL-u ustanowienia podatku importowego nie zakończyła się sukcesem.

\footnotetext{
5 J. Solska, P. Tarnowski, Miód z octem, „Polityka” 2002, nr 5, s. 21-22.

${ }^{6}$ Budżet warunkowy uzależniał wypłatę części świadczeń od wpływów z VAT, cf. J. Jankowiak, Dramat $w$ jednym akcie (i czterech odsłonach), „Tygodnik Powszechny” 2003, nr 30 [online]. Dostępny w internecie: <http://www2.tygodnik.com.pl/tp/2820/main02.php> [data dostępu: 4.06.2013].

7 J. Solska, Obywatel zapłaci, „Polityka” 2001, nr 44, s. 24.

8 J. Paradowska, Studniówka Millera, „Polityka” 2002, nr 5, s. 19.

${ }^{9}$ A. Grzeszczak, Bileciki do kontroli, „Polityka”2001, nr 50, s. 15.
} 
Stymulantami polskiej gospodarki, proponowanymi przez ówczesnego ministra gospodarki Jacka Piechotę oraz ministra infrastruktury Marka Pola, miały stać się dwa rządowe programy: Przede wszystkim przedsiębiorczość oraz Infrastruktura - klucz do rozwoju. Pierwszy $\mathrm{z}$ nich zakładał wprowadzenie ułatwień dla rozwoju przedsiębiorczości za pomocą likwidacji skomplikowanych ram formalnych towarzyszących uruchamianiu i prowadzeniu działalności nowej firmy. Ponadto dążył do zwiększenia nacisku na upowszechnienie zatrudnienia w sektorach wytwórczych i usługowych. Czterdzieści planowanych ustaw miało dotyczyć zmian w każdym lub prawie każdym aspekcie funkcjonowania firmy: procesie rejestracji i prowadzenia przedsiębiorstwa, zapisów prawa pracy, wypełniania formalności rozliczeniowych i ubezpieczeniowych, sprawozdań oraz potencjalnych kontroli ze strony państwa ${ }^{10}$. Drugi program opierał się na wspieraniu budownictwa mieszkaniowego, które dzięki tanim kredytom i wydłużonemu czasowi spłaty, uległoby wyraźnemu pobudzeniu. Kolejne założenia projektu mówiły o wprowadzeniu zasad konkurencji rynkowej do sektora telekomunikacji oraz budowie nowych dróg (autostrad) łącznie z modernizacją już istniejących (ekspresowych i szybkiego ruchu). Ponoszenie powstałych kosztów pozostawałoby w gestii budżetu państwa, Unii Europejskiej (fundusze pomocowe) oraz koncesjonariuszy pochodzących z grupy partnerstwa publiczno-prawnego ${ }^{11}$. Natomiast sama realizacja programu miałaby pozytywnie oddziaływać na przedsiębiorczość, bezpieczeństwo i jakość życia oraz aktywną walkę z bezrobociem (tworzenie nowych miejsc pracy). W 2003 r. minister transportu zaproponował wprowadzenie dodatkowego obciążenia finansowego dla właścicieli samochodów ${ }^{12}$. Winiety miały być jedną z form finansowania budowy autostrad w Polsce, jednak bez poparcia PSL-u pomysł nowego podatku drogowego upadł.

Pomimo starań rządu deficyt w sektorze finansów publicznych utrzymywał tendencję wzrostową, osiągając pod koniec roku 2002 43,6 mld zł. Odpowiadało to 5,9 $\mathrm{PKB}^{13}$. W ratowaniu finansów państwa nie pomagało usztywnienie wydatków: pomocy pieniężnej dla Funduszu Ubezpieczeń Społecznych i Funduszu Pracy, kosztów obsługi długu publicznego oraz pozostałych nakładów.

\footnotetext{
10 B. Michalak, M. Wincławska, Rząd Leszka Millera (19 X 2001-2 V 2005) [w:] Rzq̨dy koalicyjne III RP, red. M. Chmaja, Olsztyn [cop. 2006], s. 244.

11 Ibidem, s. 245.

12 A. Grzeszak, Wstęga szos..., „Polityka” 2002, nr 35, s. 24-26.

13 W. Bonusiak, Trzecia Rzeczpospolita (1989-2007), Rzeszów 2008, s. 200.
} 
W drugiej połowie 2002 r. Marek Belka dobrowolnie ustąpił z ministerialnego stanowiska, oficjalnie tłumacząc się wyczerpaniem pomysłów. Wśród nieformalnych powodów wymieniało się spór z premierem Millerem o obniżenie stóp procentowych oraz kształt budżetu na rok 2003. Nowym ministrem finansów został ceniony przez środowiska lewicowe profesor Grzegorz Kołodko14, który zaproponował własne rozwiązanie problemu deficytu budżetowego: abolicję podatkową. Miała ona polegać na tym, że osoby będące dłużnikami Skarbu Państwa po wpłaceniu 7,5 proc. wartości zaległych funduszy traciłyby status dłużnika. W toku prac nowa ustawa ulegała różnym modyfikacjom. W ostatecznej wersji kwota podlegająca zwrotowi wzrosła do 12 proc. Pomimo zatwierdzenia przez parlament, dokument zakwestionował prezydent Kwaśniewski, kierując go do Trybunału Konstytucyjnego. Sąd orzekł jego niezgodność z ustawą zasadniczą.

Grzegorz Kołodko, podobnie jak wspomniany Jacek Piechota, również opracował plan odnoszący się do funkcjonowania przedsiębiorstw. Znalazły się w nim m.in. zapisy o oddłużeniu „rokujących na przyszłość” firm, które znajdują się w trudnej sytuacji finansowej, pod warunkiem odprowadzenia tzw. opłaty restrukturyzacyjnej. Wysokość należności zamykała się w przedziale 1,5-15 proc., gdzie najniższą stawkę płaciłyby przedsiębiorstwa zajmujące strategiczne pozycje $\mathrm{w}$ gospodarce kraju. W przypadku firm będących wypłacalnymi, ale borykającymi się z problemem zadłużenia, istniałaby premia podatkowa prowadząca do obniżenia podstawy opodatkowania. Program Grzegorza Kołodki zakładał również wsparcie nowych firm, w których liczba zatrudnionych pracowników nie przekraczałaby 50 osób. Nagrodą za utrzymanie się na rynku $\mathrm{w}$ pierwszym roku działalności miało być zwolnienie z opłaty wstępnej na podatek dochodowy $\mathrm{w}$ roku następnym. Zwrot przyznanej ulgi byłby rozłożony w czasie (maksymalnie 5 lat). Ostatni pomysł skierowano do sektora bankowego. Powstała możliwość wpisania do kosztów uzyskania przychodu utraconych środków i kredytów w zamian za poszerzenie oferty bankowej o nowe linie kredytowe ${ }^{15}$.

Emocje w debacie publicznej wywołały również inne pomysły koalicyjnego rządu. Polskie Stronnictwo Ludowe wyszło $\mathrm{z}$ inicjatywą uchwalenia ustawy o biopaliwach, która zakładała, że do sprzedawanych w kraju paliw doszedłby obowiązek uzupełniania ich o biokomponenty pochodzące $\mathrm{z}$ oleju rzepakowego oraz spirytusu.

\footnotetext{
14 Grzegorz Kołodko był uważany za autora gospodarczych sukcesów lewicy z okresu jej rządów II kadencji sejmu RP.

15 B. Michalak, M. Wincławska, op. cit., s. 244.
} 
Pomimo różnic zdań między koalicjantami i sporu o procentowy udział nowych składników w paliwie, sejm i senat przyjęły ustawę. W dalszej kolejności trafiła ona do prezydenta Aleksandra Kwaśniewskiego, który zawetował kontrowersyjny akt prawny ze względu na sprzeciw różnych zainteresowanych środowisk ${ }^{16}$. Dalszy ciąg nieporozumień między SLD i PSL-em był widoczny w dyskusjach i rozbieżnym stanowisku dotyczącym wprowadzenia obowiązkowych winiet. Partia Jarosława Kalinowskiego przy pomocy opozycji odrzuciła pomysł ministra Marka Pola, co przelało czarę goryczy wobec nielojalnego PSL-u. W marcu 2003 r. ludowcy zostali zmuszeni do opuszczenia koalicji rządzącej ${ }^{17}$, która przekształciła się w rząd mniejszościowy.

Prognozy gospodarcze opracowywane na 2003 r. były bardziej optymistyczne niż rok wcześniej. Od połowy 2002 r. następowało ożywienie ekonomiczne, a wzrost gospodarczy planowany na 3,5 proc. w rzeczywistości wyniósł 3,7 proc. Nie udało się pozyskać jednak wszystkich przewidywanych dochodów. Sporym sukcesem stało się obniżenie deficytu budżetowego do 4,5 proc. PKB. Dla ministra finansów te osiągnięcia były jednak niewystarczające - ostatecznie podał się do dymisji. Grzegorza Kołodkę zastąpił Andrzej Raczko. W międzyczasie zmienił się również minister skarbu obowiązki odchodzącego Wiesława Kaczmarka przejął podsekretarz stanu w Kancelarii Prezesa Rady Ministrów (KPRM) Sławomir Cytrycki. Nowym wicepremierem (po Kołodce) został Jerzy Hausner, który na początku roku stanął na czele nowego dużego Ministerstwa Gospodarki i Pracy. Jerzy Hausner przedstawił pierwszy plan naprawy finansów państwa, ale jego propozycje nie doczekały się realizacji. W sprawie przebudowy systemowej górnictwa państwo systematycznie zmniejszało zadłużenie nierentownej gałęzi gospodarki wobec Skarbu Państwa. Przykładowo w 2002 r. umorzono prawie $18 \mathrm{mld}$ zł i przekazano ponad $810 \mathrm{mln}$ zł. na restrukturyzację zatrudnienia i likwidację kopalń. W ciągu trzech lat liczba górników zmalała o 46 tys., a towarzyszyły jej liczne protesty samych zainteresowanych ${ }^{18}$. Wydatki na górnictwo wpłynęły ponadplanowo na zwiększający się dług publiczny. Od 2001 r. na przestrzeni czterech lat zwiększył się on z 302 mld do poziomu 444 mld zł(odpowiednio z 39,9 proc. PKB do 50,2 proc. PKB).

\footnotetext{
16 Przyjęcie ustawy było równoznaczne z osiągnięciem sporych zysków przez rolników oraz właścicieli gorzelni. Protestowali natomiast: potentat paliwowy PKN Orlen, tłumacząc sprzeciw wymogiem wielu kosztownych inwestycji, oraz część właścicieli samochodów, którzy obawiali się wpływu nowego paliwa na silnik, cf. K. Grzegrzółka, K. Trębski, Pół baku rzepaku?, „Wprost” 2002, nr 50 [online]. Dostępny w internecie: <http://www.wprost.pl/ar/36987/Pol-baku-rzepaku/?pg=0> [dostęp: 28.04.2013]; A. Dudek, op. cit., s. 454 .

17 W. Roszkowski, Najnowsza historia Polski 1980-2006, Warszawa 2007, s. 272-273.

18 Cf. A. Dudek, Historia polityczna Polski 1989-2005, s. 449.
} 
$\mathrm{Na}$ początku 2004 r. rząd przyjął kolejny dokument traktujący o naprawie finansów państwa. Drugi projekt wicepremiera Jerzego Hausnera (nazwany później „planem Hausnera”) zakładał przeprowadzenie restrukturyzacji Polskich Kolei Państwowych, górnictwa oraz służby zdrowia. Hausner opowiadał się za cięciami w administracji (ograniczenie etatów i samochodów służbowych), a także za zmianami w strukturze socjalnych wydatków państwa przez redukcję finansowania z budżetu pracowniczego i rolnego systemu ubezpieczeń (KRUS). Dodatkowo planowano wprowadzenie modyfikacji wydatków przeznaczonych na obronność kraju19. Plan Hausnera pomimo racjonalnych propozycji, nie został w pełni zrealizowany. Dużą rolę w jego ograniczaniu odegrały poszczególne grupy nacisku, których miały dotyczyć zapowiadane zmiany. Sposobem na przyśpieszenie tempa wzrostu PKB było obniżenie stawki podatku dla osób prawnych (CIT) do 19 proc., co miało stymulować rozwój przedsiębiorczości w Polsce, a dodatkowo wywołało kontrowersje wśród lewicowych sympatyków i wyborców SLD ${ }^{20}$. Wysiłki państwa nie zdołały zapobiec występowaniu innych problemów (takich jak niewydolna administracja, niekoherentne przepisy, rozszerzająca się korupcja czy wydłużony okres postępowania na drodze sądowej), które skutecznie odstraszały potencjalnych inwestorów i biznesmenów. Obrazem tej sytuacji była 54 pozycja wśród krajów posiadających ułatwienia w prowadzeniu własności gospodarczej w rankingu stworzonym przez Bank Światowy w 2004 r. ${ }^{21}$ Nadzieje na wzrost gospodarczy pokładano $\mathrm{w}$ inwestycjach zagranicznych koordynowanych przez rząd Leszka Millera. Od roku 2002 w ciągu dwóch lat ich poziom wzrósł z 6 do prawie 8 mld dolarów ${ }^{22}$.

Kondycja finansowa państwa zmieniała się z roku na rok. Od początku kadencji dług publiczny wzrastał nieprzerwanie, osiągając w 2004 r. wartość prawie o 50 proc. większą niż trzy lata wcześniej. Podobny trend charakteryzował deficyt budżetowy. Mimo spadku w 2003 r., rok później wynosił już 5,9 proc. PKB. Obniżyła się inflacja, natomiast wzrost gospodarczy wykazywał znaczną poprawą. Wskaźnik wzrostu poziomu cen podlegał stopniowej deprecjacji z 3,6 proc. w 2001 r. do 0,8 proc. rok później. W 2004 r. zmienił się sposób wyznaczania celu inflacyjnego. Zamieniono

19 Cf. A. Dryszel, Cięcie Hausnera, „Przegląd” 2003, nr 42 [online]. Dostępny w internecie: <http://www.przeglad-tygodnik.pl/pl/artykul/ciecie-hausnera> [dostęp: 29.04.2013].

${ }^{20}$ Wprowadzenie liniowego podatku 19 proc. dla przedsiębiorców było sprzeczne z myślą lewicową, z którą utożsamiał się SLD, cf. K. Trębski, J. Piński, Liniowiec Millera, „Wprost” 2004, nr 52 [online]. Dostępny w internecie: <http://www.wprost.pl/ar/71287/Liniowiec-Millera/?I=1152> [dostęp: 30.04.2013].

${ }^{21}$ Cf.A. Dudek, op. cit., s. 449.

22 Ibidem, s. 449. 
dotychczasową „wielkość do osiągnięcia na koniec roku” na „wielkość osiąganą na bieżąco"23. W przypadku realnego PKB zmieniał się on dynamicznie - od 1,4 proc. w 2002 r. przez 3,8 proc. w 2003 r. do 5,4 proc. w roku 2004 i był to lepszy wynik niż przewidywany na początku kadencji przez pierwszego ministra finansów w tym rządzie Marka Belkę. Dzięki wysokiemu PKB Polska rozwijała się szybciej od wielu krajów ówczesnej Unii Europejskiej, co stanowiło atut dla państwa mającego niebawem wejść do Wspólnoty.

\section{Rolnictwo}

Sytuację w rolnictwie premier Leszek Miller lakonicznie opisał w exposé słowem „zapaść”, które bezpośrednio rzutowało na kondycję polskiej wsi. Wśród przyczyn kryzysu, oprócz hamującego wzrostu gospodarczego i jego następstw (bezrobocie, inflacja), wymieniono również niełatwe procedury dostosowujące polskie rolnictwo do wymogów Unii Europejskiej oraz długi czas oczekiwania na efekty zmian już wprowadzonych ${ }^{24}$. Receptą na poprawę sytuacji miało być uchwalenie przepisów regulujących należności dla rolników dostarczających wyprodukowaną żywność, zwiększenie kontroli na granicach w przypadku importu i eksportu wraz wprowadzeniem kaucji tranzytowych, respektowanie norm jakościowych oraz uregulowanie wytycznych obrotu ziemią ${ }^{25}$. Reforma rolnictwa miała odbywać się równolegle z negocjacjami Polski o przystąpienie do Unii Europejskiej i wymaganymi przez „kraje piętnastki” zmianami.

Pierwsze dyskusje nad modyfikacją rolnictwa pojawiły się na początku $2002 \mathrm{r}$. Komisja Europejska (KE) wystąpiła z propozycją długiego okresu przejściowego w sprawie dopłat dla rolników. W pierwszym roku członkostwa nasz kraj miał otrzymać 25 proc. dopłat bezpośrednich, które co roku, aż do 2013, czyli osiągnięcia 100 proc. byłyby podwyższane. Ogółem do 2006 r. Polska otrzymałaby ponad $800 \mathrm{mln}$ euro pomocy w sektorze rolniczym. Do otrzymania subwencji kwalifikowało posiadanie przez minimum 5 lat pola uprawnego o powierzchni nie mniejszej niż 0,3 ha. Pomysł KE doprowadził do nerwowej reakcji w rządzie. Polskie Stronnictwo Ludowe kategorycznie

\footnotetext{
${ }^{23}$ Cf. W. Bonusiak, op. cit., s. 202.

${ }^{24}$ KPRM, Raport otwarcia. Stan polskich spraw u progu działania rzq̨du SLD-UP i PSL (jesień 2001), Warszawa 2001, s. 70.

${ }^{25}$ Idem, Expose Prezesa Rady Ministrów Leszka Millera z 2001 roku [online]. Dostępne w internecie: $<$ www.poprzedniastrona.premier.gov.pl> [dostęp: 10.11.2012].
} 
nie zgodziło się na przyjęcie postulatów, uzależniając od tego dalsze trwanie koalicji. W lutym minister rolnictwa Jarosław Kalinowski przebywając z wizytą w Brukseli, zapowiedział możliwość zerwania prowadzonych rozmów o liberalizacji handlu żywnością na wypadek nieprzyznania Polsce pełnej wartości dopłat bezpośrednich. Posunięcie przewodniczącego PSL-u było odmienne od stanowiska polskiego Urzędu Komitetu Integracji Europejskiej, co wywołało kolejne nieporozumienia wśród koalicjantów. W międzyczasie pojawił się problem z procedurami nabywania polskiej ziemi przez obcokrajowców, który udało się korzystnie rozwiązać podczas wizyty komisarza ds. poszerzenia Unii - Güntera Verheugena ${ }^{26}$. Ostateczną wielkość dopłat polska delegacja wynegocjowała dopiero na szczycie UE w Kopenhadze 13 grudnia 2002 r. Zgodnie z ustaleniami Polska miała otrzymać dotacje w wysokości 55, 60 i 65 proc. w latach następnych, przy jednoczesnym wsparciu finansowym ze strony rządu 27 .

\section{Polityka społeczna}

\section{Zatrudnienie i ochrona miejsc pracy}

Projekt wsparcia zatrudnienia i ochrony miejsc pracy w przedwyborczym dokumencie w głównej mierze odnosił się do ludzi młodych, którzy w tym czasie byli najbardziej narażeni na bezrobocie. Kluczowym rozwiązaniem miał być program Pierwsza praca pomagający zdobyć wykształcenie absolwentom szkół średnich i wyższych. Zapowiadano również przekazanie większych środków z Funduszu Pracy na umowy, staże i szkolenia. Jednocześnie postulowano o poszerzenie kompetencji samorządów w walce $\mathrm{z}$ bezrobociem i wprowadzenie modyfikacji do prawa pracy. Duże nadzieje pokładano w efektywnym wykorzystaniu funduszy unijnych, dzięki którym będzie możliwe zakładanie nowych firm oraz tworzenie miejsc pracy (poprawa sytuacji na rynku zatrudnienia). Priorytetem było również unormowanie zasad okresu wychowawczego dziecka dostępnego dla obojga rodziców oraz (po jego zakończeniu) niezakłócony powrót do pracy.

Raport otwarcia diagnozujący polską gospodarkę w 2001 r. przyniósł nienajlepsze informacje o rynku pracy. Spowolnienie gospodarki skutkowało wciąż rosnącym poziomem bezrobocia, najdotkliwiej odczuwanym przez ludzi młodych. Aby ratować sytuację, rząd opracował wspomniany program Pierwsza praca mający na celu

\footnotetext{
26 M. Gędek, Oligarchia polska, czyli historia Polski 1989-2006, Lublin 2008, s.330-331.

27 Ibidem, s. 361.
} 
walkę $\mathrm{z}$ bezrobociem wśród młodzieży, połączoną $\mathrm{z}$ jednoczesną aktywizacją zawodową. Główne postulaty odnosiły się do obniżenia kosztów pracy, które ponosiłby pracodawca prowadzący małą lub średnią firmę i zatrudniający absolwentów. Państwo dopłacałoby do składki ubezpieczeniowej lub oferowało zatrudniającemu możliwość rezygnacji $\mathrm{z}$ płacenia innej niż zdrowotna składki. Ponadto rozwiązania prezentowanego planu dotyczyły upowszechnienia w szkołach średnich i na uczelniach wyższych wiedzy o rozpoczęciu własnej działalności i samozatrudnieniu, a także zachęcania do podejmowania takiej aktywności. W ośrodkach akademickich miały powstać biura specjalizujące się $\mathrm{w}$ doradztwie zawodowym oraz pośredniczące $\mathrm{w}$ poszukiwaniu pracy dla kończących studia. Kładziono nacisk na możliwość zdobycia doświadczenia poprzez pracę $\mathrm{w}$ formie wolontariatu $\mathrm{w}$ organizacjach publicznych, rządowych i pozarządowych. Program był skorelowany z innym rządowym planem Przede wszystkim przedsiębiorczość, lecz mimo to nie uzyskał wymaganego wsparcia w sejmie. Przeciwdziałanie bezrobociu nie odnosiło takich efektów, jakich się spodziewano. W 2003 r. co piąty obywatel zdolny do pracy pozostawał bez zatrudnienia $^{28}$. Dopiero rok później udało się zahamować postępujące bezrobocie i nieznacznie obniżyć negatywny trend, co było zapowiedzią nadchodzącej stopniowej poprawy w tym sektorze.

\section{Zabezpieczenie i pomoc społeczna}

Projekt reformy pomocy społecznej koalicji posłów Sojuszu i Unii Pracy zakładał wprowadzenie dwóch wskaźników: minimum socjalnego i granicy ubóstwa, na których będzie opierał się system zasiłków rodzinnych i świadczeń pomocy społecznej. Natomiast odpowiednie dodatki pieniężne na dziecko przysługiwałyby rodzinom, których dochody nie przekraczałyby minimum socjalnego lub osiągały granice ubóstwa. Warunkiem wypłaty pieniędzy byłaby kondycja budżetu kraju. Jednocześnie pomysłodawcy dążyli do sytuacji, aby to państwo (za pomocą wypłacanych gratyfikacji pieniężnych) motywowało obywateli do samodzielności finansowej. Dla SLD priorytetem miały być też aktywne formy wsparcia, takie jak dopłaty (refundacja części wynagrodzenia) dla pracodawcy zatrudniającego osobę korzystającą $\mathrm{z}$ pomocy społecznej. Oprócz organizacji przyznawania i wypłaty świadczeń, wnioskodawcy

\footnotetext{
28 M. Bukowski, P. Lewandowski, I. Magda, J. Zawistowski, Praca i wzrost [w:] Zatrudnienie w Polsce 2005, red. M. Bukowski, Warszawa 2005, s. 22.
} 
zaproponowali regulację współpracy między opieką społeczną i jej ośrodkami, powiatowymi urzędami pracy, władzami lokalnymi oraz zakładami pracy. Również szkoły w mniej zamożnych gminach zostałyby objęte system pomocy socjalnej dzięki programowi Posiłek dla ucznia czy Wyprawka szkolna. Inne trudności, jakie koalicja SLD-UP zamierzała pokonać, obejmowały zapewnienie dostępu do opieki przedszkolnej (oraz dalszej edukacji) dzieciom i młodzieży z rodzin ubogich i zaniedbanych wychowawczo oraz pomoc ofiarom patologii rodzinnych. W ramach struktury pomocy społecznej naprawiono by system emerytalny, poddany dyskusyjnej reformie przez poprzedni rząd. Najważniejszym zadaniem w tej kwestii było wprowadzenie sprawnej informatyzacji Zakładu Ubezpieczeń Społecznych, która umożliwiłaby bezbłędną i terminową obsługę, sprawne transfery środków do II filara oraz regulację zaległości. Dodatkowo, planowano zachęcać prawnie i finansowo do inwestowania w III filar, a termin waloryzacji emerytur (uwzględniający przyszły wzrost płac) zostałby przesunięty w czasie (przyśpieszony o 3 miesiące).

Trudna sytuacja finansowa państwa nie sprzyjała zwiększaniu wydatków publicznych na pomoc społeczną. Oszczędności szukali wszyscy pojawiający się i odchodzący ministrowie gospodarki, opowiadający się za znacznym ograniczeniem wydatków publicznych wraz z ustanowieniem nowych podatków, co miałoby stopniowo zmniejszać deficyt budżetowy. Przykładowo w 2003 r. Jerzy Hausner zaproponował redukcję kwoty środków płatniczych, jakie państwo przeznacza na administrację i zabezpieczenia socjalne. W ostatnim przypadku planowano weryfikację rent, która skutkowałaby odebraniem tych niesłusznie przyznanych. Drugim pomysłem było zamrożenie waloryzacji emerytur przy niskiej inflacji. Zamierzano także zlikwidować Fundusz Alimentacyjny ${ }^{29}$. Oprócz tego pojawiły się plany wydłużenia wieku emerytalnego, uzależnienia od dochodu składek na ubezpieczenie rolników, zniesienia emerytur pomostowych czy ograniczenia zasiłków chorobowych ${ }^{30}$.

Aczkolwiek postulaty ministra Jerzego Hausnera miały charakter kontrowersyjny, a ich skutki były wymierzone w najmniej zamożnych, to jednak przeliczenia Ministerstwa Gospodarki i Pracy co do potencjalnych oszczędności były realne ze względu na dużą liczbę osób korzystających ze świadczeń, zwłaszcza w sytuacji, kiedy wydatki państwa co roku stawały się wyższe. Pomimo wysiłków rządu

\footnotetext{
${ }^{29}$ R. W. Walenciak, Wicepremier w szatach liberała, „Przegląd” 2003, nr 47 [online]. Dostępny w internecie: <http://www.przeglad-tygodnik.pl/pl/artykul/wicepremier-szatach-liberala> [dostęp: 29.04.2013]. 30 R. Bugaj, Nie umierać za Hausnera, „Przegląd” 2004, nr 11 [online]. Dostępny w internecie: <http://www.przeglad-tygodnik.pl/pl/artykul/nie-umierac-za-hausnera> [dostęp: 29.04.2013].
} 
system świadczeń społecznych nie działał tak jak powinien. W 2003 r. Ministerstwo Pracy przedstawiło raport, z którego wynikało, że 1,5 mln osób zdolnych do pracy niezasłużenie otrzymuje renty. W grupie wiekowej 20-64 odpowiada to 13 proc. ogółu, co plasowało Polskę w niechlubnej czołówce państw o największej liczbie rencistów ${ }^{31}$. Unikanie cięć socjalnych jest charakterystyczne dla ugrupowań o lewicowej wrażliwości, jednak w przypadku partii (lub właściwiej koalicji) rządzącej brak zdecydowanych, racjonalnych działań (w późniejszym czasie) przełoży się na pogarszającą się sytuację ekonomiczną Polski.

\section{Edukacja i sport}

Wśród przedwyborczych propozycji koalicji SLD-UP znalazło się m.in. upowszechnienie wychowania szkolnego dla dzieci do lat 5 czy stopniowe obniżanie wieku obowiązku szkolnego (do 6 lat) wraz $\mathrm{z}$ wprowadzeniem modyfikacji programowych w cykl nauczania. Postulowano wzmocnienie nacisku na naukę języków obcych od pierwszej klasy podstawowej i ulepszenie systemu kształcenia nauczycieli (także kształcenia ustawicznego). Priorytetem było, połączone z upowszechnieniem nowych metod edukacji (Internet, telewizja), wyposażenie pracowni komputerowych w szkołach. Wspomniano również o zmianach w strukturze szkolnictwa, które miały promować średnie wykształcenie. Co do szkolnictwa wyższego, zmiany miały dotyczyć tworzenia nowych ośrodków akademickich, uporządkowania statusu doktorantów (wzrost ich ilości, wprowadzenie studiów habilitacyjnych). Planowano także włożyć więcej wysiłku w działania zmierzające do zahamowania odpływu kadry z uczelni czy zacieśnienia związków nauki z gospodarką (badania i rozwój, parki technologiczne, informatyzacja, kształcenie $\mathrm{w}$ zawodach pożądanych na rynku pracy). Pozostałe postulaty odnosiły się do innych aktualnych problemów: przesunięcia terminu wdrożenia zasad nowej matury, umożliwienia skorzystania ze stypendiów socjalnych studentom placówek tak publicznych, jak i prywatnych, usprawnienia systemu kredytów studenckich czy otwierania nowych uczelni i ośrodków zamiejscowych w miejscowościach do tego przystosowanych.

Minister edukacji i sportu Krystyna Łybacka pod koniec 2001 r. zdecydowała o „przesunięciu” terminu zdawania nowego egzaminu dojrzałości na rok szkolny 2004/2005, czyli wtedy, gdy „aktualni gimnazjaliści, którzy realizują edukację wedle

\footnotetext{
31 A. Dudek, op. cit., s. 450.
} 
nowego programu, dojdą do matury"32. Początkowo wprowadzenie zreformowanej matury było planowane na wiosnę 2002 r. Natomiast z kanonu przedmiotów obowiązkowych wycofano matematykę. W 2002 r. rząd w ramach oszczędności i ratowania finansów państwa zamroził płace nauczycieli i pracowników szkół wyższych ${ }^{33}$. Jesienią tego samego roku sejm przyjął nowelizację ustawy o oświacie, która wprowadziła kilka modyfikacji. Pojawił się obowiązek rocznego wychowania przedszkolnego dla sześciolatków (do tej pory tzw. „zerówka” nie była obligatoryjna) obowiązujący od 1 września 2003 r. Jednocześnie wprowadzono możliwość kształcenia się nauczycieli na dwa sposoby (studia licencjacki lub pełne magisterskie), a dodatkowo przyszłych nauczycieli języków zobligowano do zdania egzaminu z języka obcego. Natomiast pedagogów, którzy podejmą pracę w szkołach podstawowych i gimnazjach, zobowiązano do poprowadzenia dwóch przedmiotów z odrębnych dziedzin. Aby sprostać tym wymaganiom, przyjęta nowelizacja poszerzyła program studiów pedagogicznych o odpowiednie przygotowanie merytoryczne. Co więcej, wprowadzono kryterium, iż nauczyciel musiał obligatoryjnie odbyć semestralną praktykę w szkole oraz zdobyć certyfikat umiejętności informatycznych. Pozostałe zmiany dotyczyły zaś akredytacji placówek doskonalenia oraz liczby godzin nauczyciela spędzonych z uczniem ${ }^{34}$.

Za jeden z głównych celów uznano popularyzację aktywności fizycznej wśród dzieci i młodzieży. Miały temu służyć większe kwoty pieniężne przeznaczane na budowę obiektów sportowych (administrowanych przez samorządy) skupionych w osiedlowych, miejskich lub gminnych ośrodkach sportu i rekreacji. Nacisk położono także na utworzenie nowych klubów sportowych wraz z odpowiednio wykształconą kadrą trenerską oraz powołanie Powiatowych Rad Sportu Dzieci i Młodzieży, które miałyby intensyfikować dotychczasowe osiągnięcia propagujące kulturę fizyczną. W rządzie Leszka Millera za promocję aktywności fizycznej odpowiadał minister oświaty zarządzający resortem edukacji narodowej i sportu.

\footnotetext{
32 IrP, PAP, Nowa matura przesunięta na 2004/2005, „Wprost” [online], 20 października 2001 [dostęp: 28.04.2014]. Dostępny w internecie: <http://www.wprost.pl/ar/19938/Nowa-matura-przesunieta-na-20042005>.

33 D. Macieja, Zakładnicy Karty Nauczyciela, „Wprost” 2002, nr 7 [online]. Dostępny w internecie: <http://www.wprost.pl/ar/12263/Zakladnicy-Karty-Nauczyciela/?I=1003> [dostęp: 28.04.2013].

${ }^{34} \mathrm{em}$, PAP, Obowiązkowa „,zerówka”, „Wprost” [online], 12 listopada 2002 [dostęp: 28.04.2014]. Dostępny w internecie: <http://www.wprost.pl/ar/31919/Obowiazkowa-zerowka/>.
} 


\section{Ochrona zdrowia}

Propozycje naprawy funkcjonowania służby zdrowia były odpowiedzią na negatywną ocenę dokonań poprzedniego rządu. W Raporcie otwarcia pisano, że „reforma ochrony zdrowia, przygotowana i wprowadzona przez koalicję AWS-UW, doprowadziła do bardzo niekorzystnego społecznie zjawiska, jakim jest utrata poczucia bezpieczeństwa zdrowotnego obywateli naszego kraju."35 Za źródło aktualnego stanu rzeczy uważano m.in. niewystarczające nakłady finansowe przeznaczone na służbę zdrowia, wdrożenie nowego, lecz niedopracowanego systemu opieki zdrowotnej, co skutkowało - w szczególności - przesunięciem świadczeń medycznych do sektora prywatnego i ograniczeniem ich dostępności. Tym samym zarówno w programie wyborczym ${ }^{36}$, jak i Raporcie otwarcia z 2001 r. przedstawiono kilka rozwiązań zaistniałej sytuacji. Autor wniosków (po wyborach - minister zdrowia) Mariusz Łapiński postulował likwidację istniejących 17 kas chorych, a w ich miejsce powołanie od 4 do 6 regionalnych funduszy ochrony zdrowia, które współpracowałyby tak z podmiotami świadczącymi usługi medyczne, jak i z samymi samorządami. Proponował przywrócenie zobowiązań państwa wobec prowadzonej polityki zdrowotnej poprzez ustanowienie ogólnokrajowych standardów pomocy zdrowotnej oraz wzmocnienie nadzoru nad wspomnianymi regionalnymi jednostki organizacyjnymi. Zamierzał upowszechnić system lekarza rodzinnego oraz rozszerzenie skali zakresu świadczeń specjalistycznych, do realizacji których nie byłyby wymagane skierowania. Mariusz Łapiński planował także wprowadzić rejestr usług medycznych oraz kontrolę ordynacji leków. Priorytetem było wyszczególnienie sieci szpitali publicznych, których nie obejmowałaby potencjalna prywatyzacja. W planach znajdowało się również wdrażanie różnego rodzaju programów zdrowotnych dotyczących opieki nad matką i dzieckiem, profilaktyki szczepień czy rozwoju medycyny szkolnej37.

W praktyce proponowane zmiany często ulegały różnym modyfikacjom. Co prawda zlikwidowano 17 kas chorych, ale zastąpiono je jednym (a nie kilkoma) organem centralnym - Narodowym Funduszem Zdrowia - wraz z 16 oddziałami. Projekt nowej ustawy dotyczący służby zdrowia wpłynął do parlamentu w połowie 2002 r. Pomimo sprzeciwu środowisk lekarskich oraz opozycji uchwalono go na początku następnego roku. W 2004 r. ustawa została podana do Trybunału

\footnotetext{
${ }^{35}$ KPRM, Raport otwarcia..., s. 79.

${ }^{36}$ P. Walewski, Fundusz Wszelkiej Szczęśliwości, „Polityka” 2002, nr 7, s. 28.

37 Program wyborczy koalicji SLD i UP 2001 [online]. Dostępny w internecie: <www.sld.org.pl> [dostęp: 13.12.2012].
} 
Konstytucyjnego, który stwierdził konstytucyjną niezgodność. W międzyczasie akt prawny był poprawiany ponad 20 nowelizacjami, a ostatecznie po wyroku Trybunału, zmieniony. Minister zdrowia zapowiedział również podjęcie działań dotyczących uproszczenia administracji i zasad refundacji leków oraz podwyższenie $(z$ 7,75 do 8 proc.) wartości składki na ubezpieczenie zdrowotne ${ }^{38}$. Ostatni z postulatów został przyjęty 23 listopada 2002 r. na forum sejmowym. Dyskusyjne decyzje ministra Łapińskiego nie przysporzyły mu sympatii w środowisku lekarskim ani u pozostałych członków rządu. W czasie swojej kadencji (do 17 stycznia 2003 r.) wchodził w spory z ministrami finansów ${ }^{39}$ (Markiem Belką i Grzegorzem Kołodką) oraz dyrektorami poszczególnych kas chorych, którzy nie akceptowali jego decyzji. Minister Mariusz Łapiński był autorem listy leków refundowanych (zatwierdzonej 10 kwietnia 2002 r. przez sejm). Promował także medialny program „leków za złotówkę” skierowany do osób w wieku emerytalnym, który w ostateczności nie został wprowadzony. Po dwóch latach urzędowania premier Leszek Miller odwołał go ze stanowiska, następnie usunięto go z partii za formułowanie oskarżeń wobec późniejszego ministra zdrowia, ówczesnego prezydenta Rzeczypospolitej Polskiej ${ }^{40}$. Następcą Łapińskiego został Marek Balicki.

\section{Zakończenie}

Analiza problemu badawczego dotyczącego przyczyn ewolucji programowej SLD w latach 2001-2005 doprowadziła do szeregu wniosków. Warto zaznaczyć, że hipoteza o odejściu partii Millera od lewicowych wartości na skutek czynników tak wewnętrznych, jak i zewnętrznych została pozytywnie zweryfikowana.

Część proponowanych przez ówczesny rząd rozwiązań społecznogospodarczych w znacznym stopniu odbiegała od postulatów i przekonań, które są charakterystyczne dla myśli lewicowej. Redukcja świadczeń socjalnych, którą najbardziej odczuły osoby o najniższym dochodzie oraz wprowadzenie nowych podatków („podatek Belki”), zapowiedzi zamrożenia waloryzacji emerytur oraz zniesienia świadczeń pomostowych, likwidacji zasiłków chorobowych, funduszy

\footnotetext{
38 B. Michalak, M. Wincławska, op. cit., s. 246.

39 P. Walewski, Płytki oddech, „Polityka” 2001, nr 45, s. 20.

40 Oskarżenia korupcyjne wobec ministra zdrowia Leszka Sikorskiego oraz wywieranych nacisków przez Aleksandra Kwaśniewskiego dotyczących funkcjonowania Laboratorium Frakcjonowania Osocza, cf. A. Dudek, op. cit., s. 438-440.
} 
alimentacyjnych oraz pomysł wydłużenia wieku emerytalnego to nie jedyne "grzechy" lewicowego rządu. Dalej można wymieniać zbytnią liberalizację gospodarki (np. podjęcie procesu reprywatyzacji, wprowadzenie podatku liniowego CIT itd.) czy brak implementacji przygotowywanych programów (Pierwsza praca, Posiłek dla ucznia itd.), które okazały się jedynie zapowiedziami. Brak skuteczności rozwiązań w pogarszającej się sytuacji ekonomicznej kraju był najbardziej odczuwalny przez ludzi najbiedniejszych oraz miał odzwierciedlenie w recesji na rynku pracy.

Stąd nasuwa się wniosek, że proponowane przez rząd działania w zdecydowanej mierze były podyktowane zmiennymi warunkami społecznoekonomicznymi. Nienajlepsza sytuacja gospodarcza kraju zmuszała władzę do poszukiwania coraz to nowszych i bardziej efektywnych rozwiązań, wskutek czego powstawanie nowego planu ratowania finansów wiązało się ze zmianą na stanowisku ministra właściwego (podobnie było w innych resortach). Warto zauważyć, że gabinet Leszka Millera „odziedziczył” po poprzednikach zwiększającą się recesję (bezrobocie, spadek dynamiki wzrostu gospodarczego itd.). Jednak, mimo starań próby naprawy reform Buzka nie osiągnęły zamierzonego efektu, a jedynie wprowadziły dodatkowy chaos informacyjno-organizacyjny. Poszukiwanie odpowiednich metod i środków wyjścia z kryzysu doprowadziło do sięgania po rozwiązania - co prawda - racjonalne, ale dalekie od założeń lewicowości. Nie dziwi więc to, że struktury partyjne buntowały się przeciwko prowadzonej polityce, domagając się korekty planów. Proponowane przez rząd Millera rozwiązania w pewnym stopniu przyczyniły się do wewnętrznego rozkładu SLD oraz dekompozycji koalicyjnego rządu.

Kończąc, należałoby ocenić przyczyny dekompozycji SLD z pozycji wewnętrznej partii. Rządy kanclerskie Leszka Millera („kanclerzem” nazwało go PSL pod koniec trwania koalicji) oraz czasami wręcz autorytarny model podejmowania decyzji były jednym z problemów. Ponadto sposób zachowania się poszczególnych członków SLD może stać się tematem do oddzielnej dyskusji. Sprawowanie władzy silną ręką przez premiera po części wynikało zapewne $\mathrm{z}$ odpowiedzialności, jaką on i jego gabinet podjęli za kraj po wyborach w 2001 r. Z drugiej strony „kancleryzm” Leszka Millera mógł $\mathrm{w}$ pewnym stopniu wypływać z poczucia siły po wygranych wyborach oraz przekonania, że tylko zdecydowane działania mogą zażegnać postępującą recesję gospodarczą oraz utrzymać jedność partii. 